\title{
INVENTORY OF SPERMATOPHYTA OF TANJUNG SETIA KRUI BEACH VEGETATION AS A SOURCE OF BIOLOGICAL LEARNING
}

\author{
Suharno Zen ${ }^{1 *}$, Rinta Apriliani ${ }^{2}$ \\ ${ }^{1,2}$ Biology Education, Education Departemen, University of Muhammadiyah Metro \\ *Correspondence email: suharnozein@gmail.com
}

\begin{tabular}{|c|c|}
\hline ARTICLE INFO & ABSTRACT \\
\hline $\begin{array}{l}\text { Article history } \\
\text { Received } 28^{\text {th }} \text { of March, } 2020 \\
\text { Revised } 03^{\text {rd }} \text { of April., } 2020 \\
\text { Accepted } 15^{\text {th }} \text { of April., } 2020 \\
\text { Published } 21^{\text {st }} \text { of May, } 2020 \\
\text { Keywords } \\
\text { Inventory } \\
\text { Spermatophyta } \\
\text { Vegetation } \\
\text { Tanjung Setia Krui Beach }\end{array}$ & 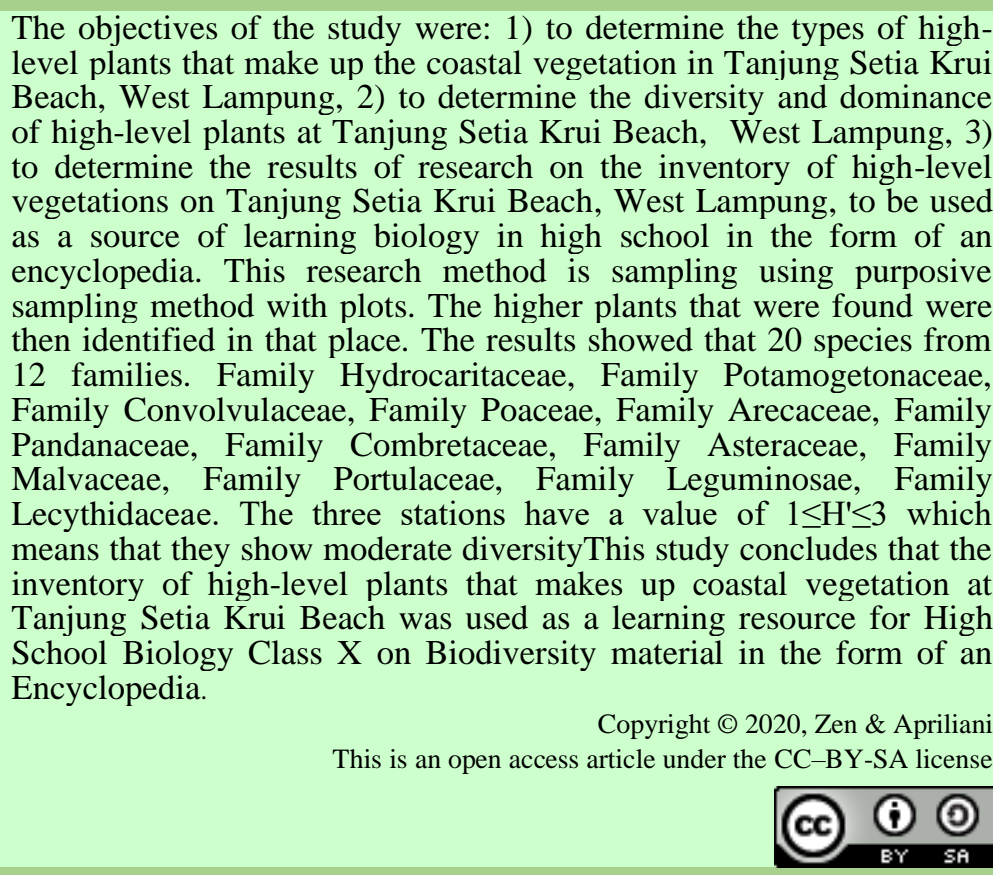 \\
\hline
\end{tabular}

\section{A. INTRODUCTION}

High-level plants are one of the constituents of coastal vegetation in Setia Krui, West Lampung, high-level plant diversity can be used as a constituent of ecosystem sustainability as a potential as a natural resource. According to Mulyani (2006) that vascular plants or tracheophytes are a group of spermatophyta plants which are grouped into closed seed plants (angiosperms) and open seed plants (gymnosperms). So with the spread of this plant will affect the preparation of vegetation that exist in coastal environments. According Fachrul (2007) that the vegetation is plant communities formed by various populations of plant species are present in one region or ecosystem, and has variation in each particular conditions ". Tanjung Setia Beach Krui has a spacious layout and are different which covers an area which is quite extensive, namely $\pm 2907.23 \mathrm{~km}^{2} \mathrm{of}$ The province of Lampung. The results of this study are in the form of an encyclopedia as a 
source of learning materials from research on high-level plant variations made in the form of an encyclopedia that students will use in learning in biodiversity material. An encyclopedia is a book summary that includes information in the form of information described based on alphabetical arrangement and usually contains pictures or photos, illustrations, thus helping someone to seek more insight from their surroundings.

\section{B. METHOD}

The approach and type of research for the inventory of high-level plants that make up the coastal vegetation at Tanjung Setia Krui Beach Lampung Lampung uses a descriptive qualitative approach. When the research was conducted on October-December 2019. The research site was carried out by Tanjung Setia Krui Beach, West Lampung. Sampling was done using purposive sampling method and using line transect technique (line transect) at 3 research stations.

Vegetation diversity then analyzed the data using the calculation of the diversity index, dominance index and validation calculations to determine the feasibility of the research results that will be used as a source of learning biology in the form of an encyclopedia.

Diversity index analysis according to Shannon and Weaner Rappe (2010):

$$
\mathrm{H}^{\prime}=-\sum\left(\frac{n i}{N} \ln \frac{n i}{N}\right)
$$

\section{Information:}

a. The value of $\mathrm{H}^{\prime}>3$ indicates that the diversity of species on a transect is high overflow.

b. Score $\mathrm{H}^{\prime} 1 \leq \mathrm{H}^{\prime} \leq 3$ indicates that the diversity of species on the transect is in abundance.

c. The value of $\mathrm{H}^{\prime}<1$ indicates that the diversity of species in a species is little or low.

For the analysis of the dominance index using the formula according to Ardhana (2012) as follows:

$$
\mathrm{ID}=\sum(\mathrm{n} . \mathrm{i} / \mathrm{N})^{2}
$$

Table 2.1. Dominance Index Category

\begin{tabular}{cc}
\hline Dominace & Category \\
\hline $0,00<\mathrm{C} \leq 0,50$ & Low \\
$0,50<\mathrm{C} \leq 0,75$ & Moderate \\
$0,75<\mathrm{C} \leq 1,00$ & High \\
\hline
\end{tabular}

Source: Rappe (2010)

Next is to calculate the feasibility percentage of the encyclopedia with the following formula: (Puspitadewi, 2014). Encyclopedia eligibility $=\sum \frac{\text { Score all aspects of all score validators maximal all aspects }}{\text { Maximum score of all aspects }}$

The percentage of eligibility obtained is then interpreted into categories based on Table 2.2. 
Table 2.2. Encyclopedia Eligibility Criteria

\begin{tabular}{cl}
\hline Average Score $(\%)$ & \multicolumn{1}{c}{ Category } \\
\hline $0-20$ & Not feasible \\
$21-40$ & Not worth it \\
$41-60$ & Decent enough \\
$61-80$ & Well wort it \\
$81-100$ & Very worth it \\
\hline
\end{tabular}

Source: Ridwan in Puspitadewi (2014)

\section{RESULTS AND DISCUSSION}

Tanjung Setia Krui Beach which has been researched for plants found 20 types of plants with 12 families including: Hydrocaritaceae, Potamogetonaceae, Convolvulaceae, Poaceae, Arecaceae, Pandanaceae, Combretaceae, Asteraceae, Malvaceae, Portulaceae, Leguminosae, Lecythidaceae. Here are the results of the calculations in Figure 3.1:
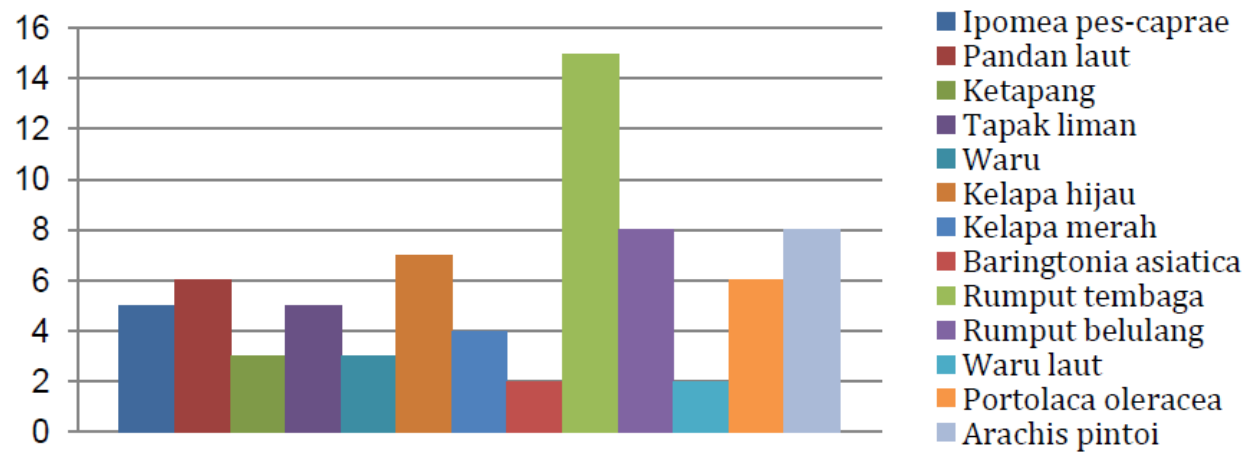

Arachis pintoi

Figure 3.1. The results of the high-level plant diversity index at station 1

This biodiversity is usually seen from the diversity index at station 1, which is 2.470. So the value of $1 \leq \mathrm{H}^{\prime} \leq 3$ can be categorized as moderate, if the diversity is between one to three, so based on these criteria, the diversity of high-level plant species that make up the coastal vegetation in the area is moderate, because the condition of the coastal area has differences in species composition and the number of individual vegetation so that it affects the value of the diversity of each type of growth rate according to Sinery (2015).
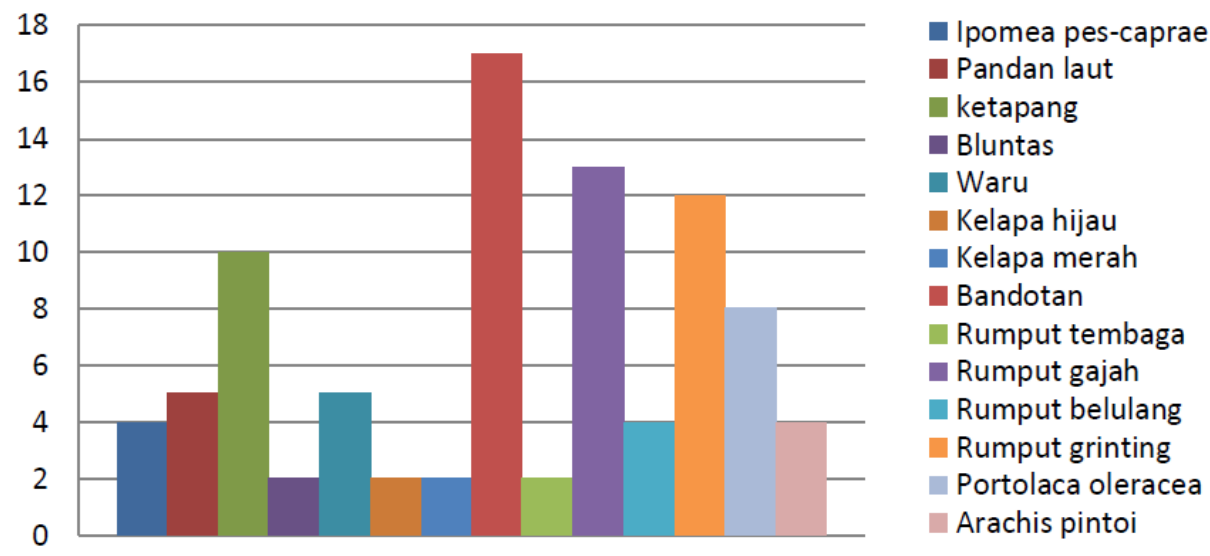

Figure 3.2. Diversity index results for stations 2 .

The high-level plant diversity index on the Tanjung Setia coast at station 2 is 2.396. Whereas the value of $1 \leq \mathrm{H}^{\prime} \leq 3$ is categorized as moderate, if the diversity is between 
one and three, so based on these criteria, the diversity of high-level plant species that make up the coastal vegetation in the area is moderate, because the condition of the coastal area has differences in the composition of types and numbers. individual vegetation so that it affects the diversity value of each growth level (Sinery, 2015).

Seagrass diversity index is 1.061 . Whereas the value of $1 \leq \mathrm{H}^{\prime} \leq 3$ is categorized as moderate, if the diversity is between one and three, so based on these criteria, the diversity of high-level plant species that make up the coastal vegetation in the area is moderate, because the condition of the coastal area has differences in the composition of types and numbers. individual vegetation so that it affects the diversity value of each growth rate (Sinery 2015). This is also in accordance with the opinion of Odum (1993) in Sinery (2015) which states that a community is considered to have moderate species diversity if the community is composed of several types (types) and several dominant types .

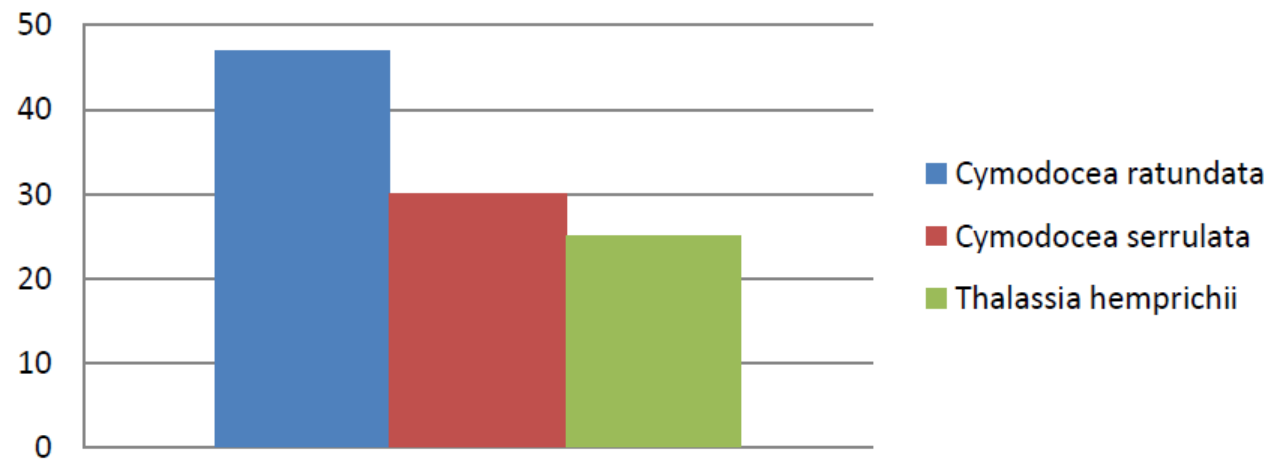

Figure 3.3. Diversity index results for stations 3 .

The results of the research that have been carried out obtained the dominance index at each station 1,2 , and 3 . The following shows the value of station 1 , namely 0.112 , station 2 is 0.108 , station 3 is 0.358 . Based on the data that is obtained from third to the station, get dominance index values ranging from 0.112 to 0.358 . The value obtained from 3 (three) stations shows a value that is categorized as low. According to Rappe (2010), this dominance index value shows a value close to 0 which means there is no dominance of a type in an ecosystem. This is also in accordance with the statement of Odum (1993) in Ridwan, et al. (2016) who reported that a low dominance index value indicates a low concentration (no one is dominant). So that in Tanjung Setia Beach there is no concentration of certain types of high-level plant communities .

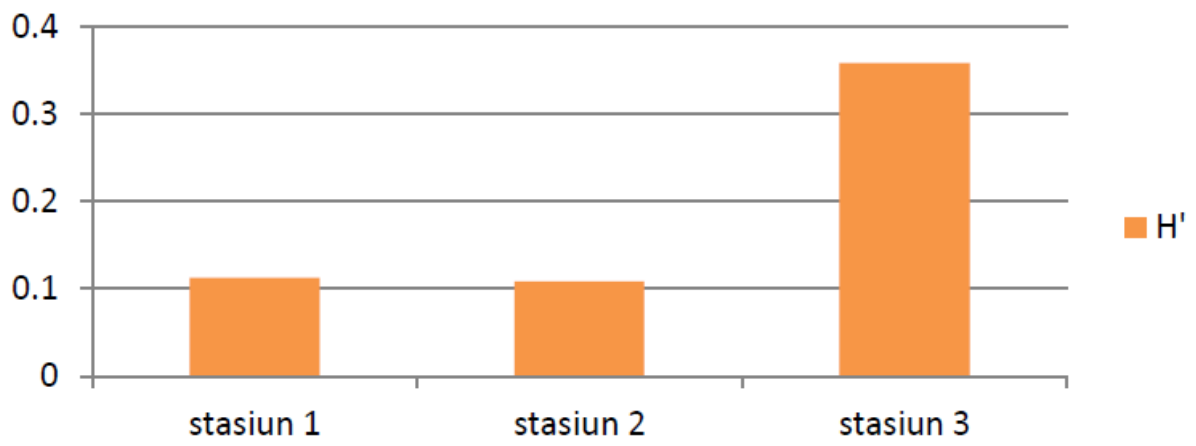


Figure 3.4. The results of the dominance index for each station 1,2 and 3.

\section{Encyclopedia}

The results of the expert validation questionnaire analysis by lecturers regarding the encyclopedia books that have been made get an average percentage of 91\% (Table 3.1), with that much percentage it is classified as very strong by the opinion of Ridwan and Akdon (2013).

Table 3.1. Feasibility Results of Information Sources in the Form of Books

\begin{tabular}{|c|c|c|c|c|c|c|}
\hline \multirow[t]{2}{*}{ No } & \multirow[b]{2}{*}{$\begin{array}{l}\text { Assessment Indicators of First } \\
\text { Expert }\end{array}$} & \multirow[b]{2}{*}{$\begin{array}{c}\text { Assessment Indicators of } \\
\text { Second Expert }\end{array}$} & \multicolumn{2}{|c|}{ Score } & \multirow[b]{2}{*}{ Average } & \multirow[b]{2}{*}{ Criteria } \\
\hline & & & $\begin{array}{l}\text { First } \\
\text { expert }\end{array}$ & $\begin{array}{c}\text { Second } \\
\text { expert }\end{array}$ & & \\
\hline 1 & $\begin{array}{l}\text { A mix of colors and writing on } \\
\text { attractive cover. }\end{array}$ & $\begin{array}{l}\text { The breadth of material in } \\
\text { the encyclopedia } \\
\text { It is enough }\end{array}$ & $80 \%$ & $100 \%$ & $90 \%$ & $\begin{array}{l}\text { Very } \\
\text { strong }\end{array}$ \\
\hline 2 & $\begin{array}{l}\text { The contents of the } \\
\text { Encyclopedia are interesting } \\
\text { and the color combination is } \\
\text { right }\end{array}$ & $\begin{array}{l}\text { The material or content is } \\
\text { arranged systematically }\end{array}$ & $100 \%$ & $80 \%$ & $90 \%$ & $\begin{array}{l}\text { Very } \\
\text { strong }\end{array}$ \\
\hline 3 & $\begin{array}{l}\text { Encyclopedia already } \\
\text { corresponding }\end{array}$ & Encourage curiosity & $100 \%$ & $100 \%$ & $100 \%$ & $\begin{array}{l}\text { Very } \\
\text { strong }\end{array}$ \\
\hline 4 & $\begin{array}{l}\text { Use of measure fonts and colors } \\
\text { are correct }\end{array}$ & $\begin{array}{l}\text { Understanding } \\
\text { the information is correct }\end{array}$ & $80 \%$ & $100 \%$ & $90 \%$ & $\begin{array}{l}\text { Very } \\
\text { strong }\end{array}$ \\
\hline 5 & $\begin{array}{l}\text { Selection of Encyclopedia } \\
\text { title it's right }\end{array}$ & $\begin{array}{l}\text { he accuracy of the } \\
\text { description or content on } \\
\text { serve }\end{array}$ & $80 \%$ & $100 \%$ & $90 \%$ & $\begin{array}{l}\text { Very } \\
\text { strong }\end{array}$ \\
\hline 6 & $\begin{array}{l}\text { Pictures and captions can be } \\
\text { understood clearly }\end{array}$ & $\begin{array}{l}\text { There are unique facts to } \\
\text { increase knowledge }\end{array}$ & $80 \%$ & $80 \%$ & $80 \%$ & $\begin{array}{l}\text { Very } \\
\text { strong }\end{array}$ \\
\hline 7 & $\begin{array}{l}\text { There are explanations for diffic } \\
\text { the form of a glossary }\end{array}$ & cult terms understood in & $80 \%$ & $100 \%$ & $100 \%$ & $\begin{array}{l}\text { Very } \\
\text { strong }\end{array}$ \\
\hline
\end{tabular}

So that this encyclopedia book can be used as a source of information for readers, which is developed in terms of material and appearance that is suitable for use as a source of high school Biology learning material on Biodiversity.

\section{CONCLUSION}

Based on the research results of the inventory of high-level plants that make up coastal vegetation that have been carried out at Tanjung Setia Krui Beach, it can be concluded that:

1. High-level plants found in Tanjung Setia Krui Beach, namely 20 species from 12 families.

2. The diversity index $\left(\mathrm{H}^{\prime}\right)$ of high-level plants that make up the coastal vegetation at Tanjung Setia Krui Beach gets the value of station 1, namely 2.470, station 2 is 2.396, station 3 is 1.061 . The Dominance Index (ID) of station 1 is 0.112 , station 2 is 0.108 , station 3 is 0.358 .

3. Encyclopedia of high-level plant inventory is suitable for use as teaching material for class X high school biodiversity. 


\section{E. REFERENCES}

Ardhana, IPG. 2012. Ekologi Tumbuhan. Bali: Udayana University Press.

Fachrul, FM. 2007. Metode Sampling Bioekologi. Jakarta: Bumi Aksara.

Mulyani, S. 2006. Anatomi Tumbuhan. Yogyakarta: Kasinus.

Puspitadewi, S. 2014. Profil LKS Materi Perubahan Lingkungan Berorientasi Kurikulum 2013 untuk Melatihkan Berfikir Kritis Siswa. Jurnal Bioedu Vol 3 No 2 Mei 2014 ISSN 2302-9528.

Rappe, AR. 2010. Struktur Komunitas Ikan pada Padang Lamun yang Berbeda di Pulau Barrang Lompo. Jurnal Ilmu dan Teknologi Kelautan Tropis, vol. 2, no. 2, Desember 2010. Makasar: Hasanuddin University.

Ridwan dan Akdon. 2013. Rumus dan Data dalam Analisis Statistika. Bandung: ALFABETA. 